\title{
Characteristics of Flood Disasters in Low Floodplain Along a Big River Due to Overflow Levee Breach
}

\author{
Md. Serazul Islam and Tetsuro Tsujimoto \\ Hydraulic Engineering Laboratory, Department of Civil Engineering, Nagoya University, Japan.
}

\begin{abstract}
During flooding season, large amount of water flows through Bangladeshi river and it causes earthen levee failure and huge damage occurs in the inhabitants inside the levees. Thus it is important to recognize the process of inundation and we have attempted to do through numerical simulation. As for simulation scheme, schematic model area is considered with main channel, levee and floodplain, and they are roughly composed of the same sediment characteristics because the flood plain have been formed by flooding sediment, the levees have been made by piling up the sediment dredged from the river bed. Therefore, we treat these three components simultaneously in the simulation model. The main channel, levee, floodplain and flow parameters are selected in conformity with the study field of Sirajganj district and Jamuna River in Bangladesh. And RIC-Nays a two-dimensional numerical model for flood flow and morphology is utilized in this study upon confirmation through the experimental and other numerical study. Based on the calculated results, inundation of water and sediment in the floodplain and evolution process of levee breach are investigated. Levee breach is considered to initiate in the middle of the levee with crest opening. We change the opening size in vertical and longitudinal scales, and the inflow discharge. For the floodplain slope is also taken into account.
\end{abstract}

Keywords: Flood disasters, levee, floodplain, sedimentation.

\section{INTRODUCTION}

Levee breach flood disaster is one of the common natural hazards in Bangladesh. Flooding, levee breach and sedimentation over floodplain have become alarming problems that have severe and adverse effect on the national economy of Bangladesh. On the average, the area inundated every year is about $26,000 \mathrm{~km}^{2}$, nearly $18 \%$ of the country's total area [1]. The average flood discharges of the three main (Ganges-Brahmaputra-Meghna) rivers individually are within the range 14,000 to $100,000 \mathrm{~m}^{3} / \mathrm{s}$ [11]. The mean annual rainfall within Bangladesh varies from $1250 \mathrm{~mm}$ to $5700 \mathrm{~mm}$ [13]. During the rainy seasons (June to September), nearly a trillion cubic meter of water laden with about two billion tons of silt passes through the main rivers, it's come from upstream catchment in India, Nepal, Bhutan and China. These sediments settle over the river beds, floodplains and low lying areas during the inundation and with the recession of flood water. As a result river channels and their distributaries are silted up with sediments composed of fine sands and silts causing drainage congestion and overbank flow resulting in river embankment failure [8], [9].

Levee breached during the rainy seasons due to excess load of flooding water. Failure of levees not only increases the siltation in the river beds and floodplains but it causes huge damage in agricultural production, residents, roads and other infrastructures. Due to geographical position of Bangladesh, we do not avoid levee breach disaster and suffering to the inhabitants in the floodplain. In order to save huge amount of money, lives, agriculture and ecology, it is most important to carry out research on investigation of flood disasters over the alluvial floodplain during levee breach for the vulnerable area of Sirajganj district in Bangladesh. This kind of study is rare in the available literatures except for few numerical, field investigation and experimental studies which can be found in Tsujimoto, Mizoguchi and Maeda [14], Aureli and Mignosa [3], and Fujita and Tamura [5].

Computational simulation can make comprehensive analysis on levee breach flooding and its impacts on the entire floodplains. In this paper, we have attempted to recognize the process of inundation and sedimentation in the floodplain after levee breach in a numerical simulation scheme for different breach opening lengths, depths and discharge conditions with time.

This study is mainly aimed to improving the understanding of flood disasters in low floodplain during overflow levee breach. The specific objectives of the present study can be summarized as follows:

(i) To investigate the flow dynamics and sedimentation at specific discharge with time.

(ii) To investigate the effect of different discharges on the floodplain flow and sedimentation at specific breach length, levee crests height and duration.

(iii) To investigate the effect of different breach opening lengths in the levee on the floodplain flow and sedimentation at specific time and discharge.

(iv) To observe the levee deformation due to overflow levee breach.

\section{DESCRIPTION OF STUDY AREA}

Sirajganj district is located in the northwestern part of Bangladesh. Geographically, extension of Sirajganj District is within the area of longitude from $89^{\circ} 20^{\prime}$ west to $89^{\circ} 50^{\prime}$ ' east and in latitude it is $24^{\circ} 00^{\prime}$ south to $24^{\circ} 20^{\prime}$ north. Total area of the district is $2497.92 \mathrm{~km}^{2}$ and it is relatively a plain land area. Most of the area of this district goes under water during the rainy season. Total cultivable land is $1799.64 \mathrm{~km}^{2}$, fallow land $157.02 \mathrm{~km}^{2}$, and forestry $0.50 \mathrm{~km}^{2}$. The annual rainfall is $1610 \mathrm{~mm}$. The mighty Jamuna River is following at the right edge of the district 
[10]. Fig. 1 depicts the map of study area of Sirajganj district with Jamuna River and flood protection levee.

Embankment breach is the most common phenomenon for Jamuna River especially on Jamuna right embankment (JRE). There are so many evidence of breaching of embankment during severe flood year of 1988, 1998, 2004 and 2007. In the year 2007, JRE at Khokshabari was breached of $700 \mathrm{~m}$ out of $52 \mathrm{~km}$ total length and floodwater entered into the breached embankment at Polashpur, Meghai, Dhekuria and Shubhogaccha areas in Kazipur Upazila of Sirajganj district (The Financial Express, 27 July 2007). At least 3500 homesteads and about $6.07 \mathrm{~km}^{2}$ of croplands in 35 villages in the five Upazilla have damaged in two weeks. The five affected Upazilla was Kazipur, Sirajganj Sadar, Belkuchi, Shahzadpur and Chauhali [7].

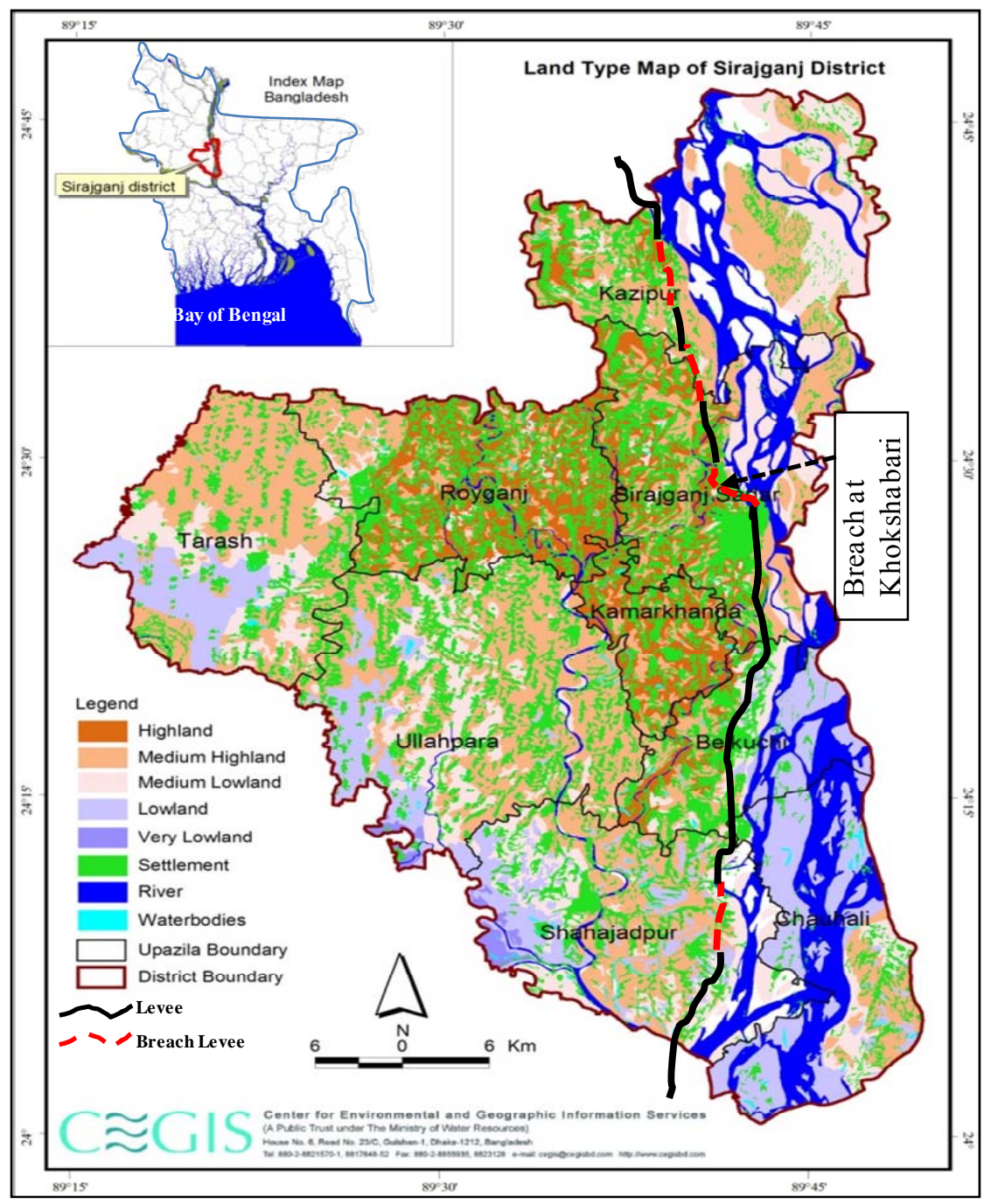

Fig. 1 Map of study area.

\section{COMPUTATIONAL MODEL}

RIC-Nays, a two dimensional (2D) model for flood flow and morphology, developed by the foundation of Hokkaido River Disasters Prevention Center, Japan is utilized in the present study.

\subsection{Hydrodynamic Equations}

The shallow-water equations for two-dimensional unsteady flow expressed in a general coordinate system are calculated on the boundary-fitted structured grids using the finite-difference method. The system of equations governing the flow consists of the continuity and horizontal momentum equations of flow. These are given in $(\mathrm{x}, \mathrm{y})$ co-orthogonal coordinate system as,

Continuity equation:

$\frac{\partial h}{\partial t}+\frac{\partial(h u)}{\partial x}+\frac{\partial(h v)}{\partial y}=0$

Momentum equations:

$\frac{\partial(h u)}{\partial t}+\frac{\partial\left(h u^{2}\right)}{\partial x}+\frac{\partial(h u v)}{\partial y}=-h g \frac{\partial H}{\partial x}-\frac{\tau_{x}}{\rho}+D_{x}$
$\frac{\partial(h v)}{\partial t}+\frac{\partial(h u v)}{\partial x}+\frac{\partial\left(h v^{2}\right)}{\partial y}=-h g \frac{\partial H}{\partial y}-\frac{\tau_{y}}{\rho}+D_{y}$ 
With: Bed Shear stresses

$$
\frac{\tau_{x}}{\rho}=C_{d} u \sqrt{u^{2}+v^{2}}, \frac{\tau_{y}}{\rho}=C_{d} v \sqrt{u^{2}+v^{2}}
$$

Diffusion terms

$$
\begin{aligned}
& D_{x}=\frac{\partial}{\partial x}\left[v_{t} \frac{\partial(h u)}{\partial x}\right]+\frac{\partial}{\partial y}\left[v_{t} \frac{\partial(h u)}{\partial y}\right] \\
& D_{y}=\frac{\partial}{\partial x}\left[v_{t} \frac{\partial(h v)}{\partial x}\right]+\frac{\partial}{\partial y}\left[v_{t} \frac{\partial(h v)}{\partial y}\right]
\end{aligned}
$$

where $h=$ depth of flow; $H=$ water stage; $u, v=$ depthaveraged velocity components in $x$ and $y$ directions, respectively; $\tau_{x}, \tau_{y}=x$ - and $y$ - components of bottomfriction, respectively; and $v_{t}=$ eddy viscosity, where depth-averaged parabolic model is applied in considering turbulence. Also, mixing length and $k-\varepsilon$ turbulence models are available in this calculation framework.

\subsection{Sediment Transport Equations}

Morphological computation involves a combination of flow fields, sediment transports, and levee breach bed evolution changes. After resolving the flow fields, the sediment transport fields are computed from the expressions of both bed load and suspended load separately. Finally, the changes in the bed topography due to total load are determined.

Two-dimensional sediment continuity equation, when only bedload contributes the change in bed level, can be expressed as,

$$
\frac{\partial z_{b}}{\partial t}+\frac{1}{1-\lambda}\left[\frac{\partial q_{x}}{\partial x}+\frac{\partial q_{y}}{\partial y}\right]=0
$$

where $z_{b}=$ bed elevation; $q_{x}, q_{y}=$ bedload transport rates per unit width in $x$ - and $y$-directions, respectively; and $\lambda$ $=$ porosity of bed materials. The bedload in the depthaveraged velocity direction $q_{b}$ can be calculated by the following (Ashida and Michiue 1972) formula [2],

$$
q_{b}=17 \tau_{*}^{3 / 2}\left(1-\frac{\tau_{*_{c}}}{\tau_{*}}\right)\left[1-\sqrt{\frac{\tau_{*_{c}}}{\tau_{*}}}\right] \sqrt{\left(s_{g}-1\right) g d^{3}}
$$

in which $\tau_{*_{c}}=$ dimensionless critical shear stress; $\tau_{*}=$ dimensionless total bed shear stress acts on the channel bed $=\frac{h I_{e}}{\left(s_{g}-1\right) d}$, with $I_{\mathrm{e}}=$ energy slope, $s_{g}=$ specific gravity; $d=$ sediment diameter. When Manning's formula is applied for $I_{\mathrm{e}}, \tau_{*}$ becomes as follows,

$$
\tau_{*}=\frac{C_{d} V^{2}}{\left(s_{g}-1\right) g d}=\frac{n_{m}^{2} V^{2}}{\left(s_{g}-1\right) d h^{1 / 3}}
$$

in which $n_{m}=$ Manning's roughness coefficient; $g=$ acceleration due to gravity; $V=$ total velocity, which can be defined as, $V=\sqrt{u^{2}+v^{2}}$.

Using the critical condition of sediment movement, Hasegawa (1983) derived a simple equation for the angle between the sediment movement direction and streamline as follows [6],

$\tan \phi=\frac{V_{n}}{V_{s}}=\frac{u_{b n}}{u_{b s}}-\sqrt{\frac{\tau_{*_{c}}}{\mu_{s} \mu_{k} \tau_{*}}} \frac{\partial z_{b}}{\partial n}$

where $V_{s}, V_{n}=$ sediment movement velocity components in $s$ - and $n$ - directions ( $s$, streamline direction; $n$, transverse direction perpendicular to streamline); $\mu_{s}, \mu_{k}$ $=$ static and kinetic friction coefficients of bed materials; $u_{b s}, u_{b n}=$ near-bed velocities in $s$ - and $n$ - directions, respectively, Whose relationship can be expressed as,

$u_{b s}=\beta_{v} V$

where $u_{b s}$ is simply related to the depth-averaged flow velocity, $\beta_{v}$ is assumed as a parabolic function by Engelund (1974) for velocity profile in depth direction and proposed as follows [4], $\beta_{v}=3\left(1-\sigma_{v}\right)\left(3-\sigma_{v}\right)$, where $\sigma_{v}=\frac{3}{\phi_{0} \kappa+1}$, in which, $\phi_{0}=$ velocity coefficient $\left(=V / u_{*}\right)$.

And, $u_{b n}=-u_{b s} N_{*} \frac{h}{r_{s}}$

where, $N_{*}$ is a constant (=7, Engelund 1974); $r_{s}$ is a radius of curvature of the streamline, calculated explicitly from the depth-integrated flow field according to Shimizu and Itakura, 1991 [12],

$$
\frac{1}{r_{s}}=\frac{1}{\left(u^{2}+v^{2}\right)^{\frac{3}{2}}}\left[u\left(u \frac{\partial v}{\partial x}-v \frac{\partial u}{\partial x}\right)+v\left(u \frac{\partial v}{\partial y}-v \frac{\partial u}{\partial y}\right)\right]
$$

Angle between $x$ - and $y$ - axis $\gamma$ can be written as, $\tan \gamma=\frac{v}{u}$. Finally the angle between sediment movement direction and the x-axis $\alpha$ can be known from, $\alpha=\phi+\gamma$ In considering suspended sediment, an exponential profile of concentration is assumed to know planar distribution of depth-averaged concentration and the 2D advectiondiffusion equations are solved.

Upwind differential scheme for advection term is utilized; also CIP (Yabe and Ishikawa 1990) method is available to apply [15]. Finally the bed deformation is determined using the 2D sediment continuity equation. Equations are solved for the unknown nodal values by an iterative process. First the flow field is computed utilizing initial and boundary conditions; the sediment transport field is then computed, to evaluate sedimentation rates, and followed by bed topography changes. 
Fig. 2 depicts the outline of the simulation steps for computation.

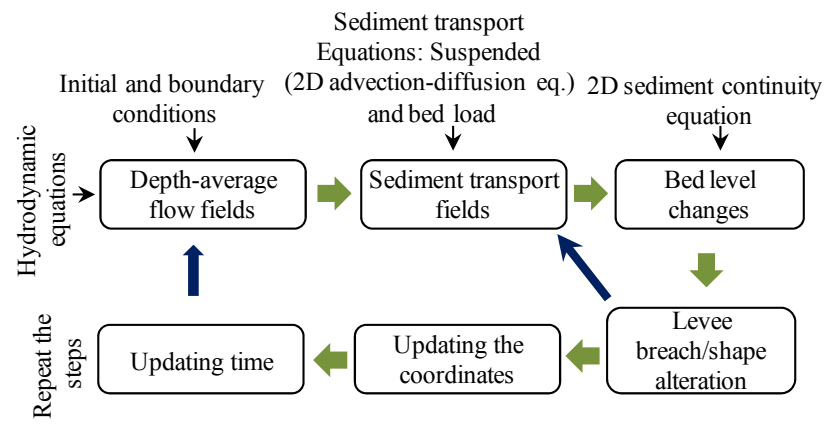

Fig. 2 Outline of model computation steps.

\section{MODEL SET-UP TO DESCRIBE EVOLUTION PROCESS OF LEVEE BREACH}

We analyze a process appearing in river, levee and floodplain in a same simulation scheme during flood. RICNays, a two-dimensional (2D) model for flood flow and morphology is utilized in the present study upon confirmation through the experimental and other numerical study. As for simulation scheme, the main channel, levee, floodplain and flow parameters are selected in conformity with the study field of Sirajganj district and Jamuna River in Bangladesh. Schematic model area is spatially limited in a part of actual field, which is 5500 times less in horizontal scale. For the first case of simulation, computation reach is $900 \mathrm{~m}$ long $(L)$ and 500 $\mathrm{m}$ wide $(Y)$ (river channel $=100 \mathrm{~m}$, levee $=25 \mathrm{~m}$ and floodplain $=375 \mathrm{~m}$ ) with a bed slope of river channel is $7.5 \mathrm{~cm} / \mathrm{km}$. Fig. $3(\mathrm{a}, \mathrm{b})$ depicts one of the model fields for simulation, which approximates the levee breach area of the JRE, Khokshabari and model layout with computational domain (square cells with $\Delta x=5 \mathrm{~m}$ and $\Delta y=5 \mathrm{~m}$ ) of river channel, breach levee and floodplain, respectively.

The country side bank regions of main channel are provided with mild slope of 1:9. Levee slope is considered as $S_{l}=1: 2$ on both country side and river side and levee height is taken as $h_{L}=5 \mathrm{~m}$ from the floodplain and $7 \mathrm{~m}$ from the river bed. Idealized flow and sediment parameters are considered in the computation: inflow discharge in the river channel before breach, $750 \mathrm{~m}^{3} / \mathrm{s}(Q)$ is considered with the peak flow of Jamuna River in flooding season, and the median size of sediment is chosen as $d_{m}=0.10 \mathrm{~mm}$ for the whole domain. Overflow starts from the hypothetical notch on top of the levee as a trigger of breach where initial breach is $100 \mathrm{~m}$ long $\left(L_{b}\right)$ and crest height is $2 \mathrm{~m}\left(h_{c}\right)$ from the floodplain. Though the river discharge has a hydrograph in general, a uniform discharge corresponding to the peak is assumed here. Solid boundary is imposed on the left side of the floodplain. In this study we use a commutation time step of $0.002 \mathrm{sec}$ and the model runs are made for 20 minutes, when the temporal variations of variables are considerably reduced.
The details of the model equations are described in the preceding section. By numerical calculation, flow behavior and process of sedimentation around the breach and in the floodplain can be described with morphological changes (see Fig. 5, 9 and 11), and can be realized spatial characteristics of the phenomena as well as temporal evolution of levee deformation.

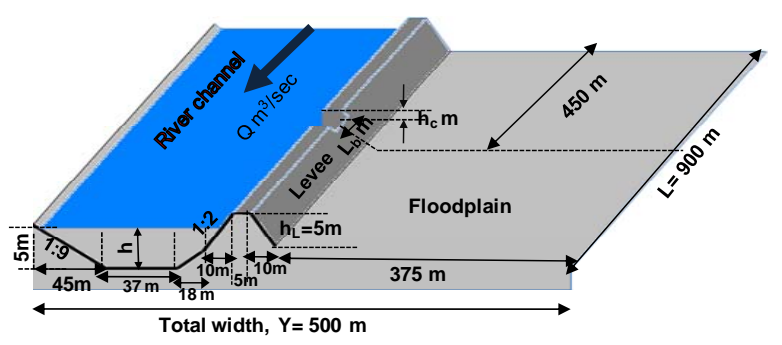

(a)

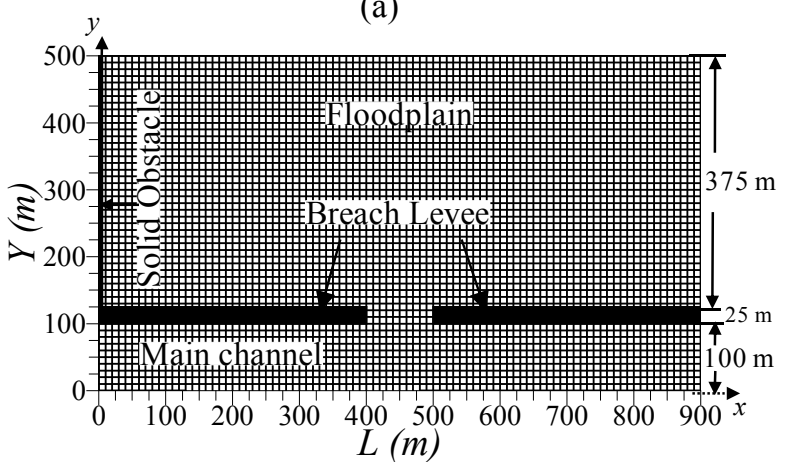

(b)

Fig. 3 (a) Simulated schematic model area; (b) Plan view of the reach with river channel, breach levee and floodplain.

\section{MODEL VALIDATION}

The present study model is verified with experimental and numerical data of Aureli and Mignosa (2001), where they investigated the flow velocity field near breach in the main channel without considering morphological change in the floodplain [3]. They were conducted the experiment in a laboratory flume which was $10 \mathrm{~m}$ long and $0.30 \mathrm{~m}$ wide and consider the breach region was $2.60 \mathrm{~m}$ long and 2.00 $\mathrm{m}$ wide. Inflow discharge and slope were maintained equal to $0.035 \mathrm{~m}^{3} \mathrm{~s}^{-1}$ and $0.1 \%$. The manning's roughness coefficient for the bottom and walls of the laboratory flume was 0.009 and breach width was considered as 0.28 m. The simulation time was $29.5 \mathrm{sec}$ for computed and measured velocity profile. Longitudinal velocity $(v)$ measurement made at different sections with distances of $\mathrm{y}=0.28,0.26$ and $0.16 \mathrm{~m}$ in the main channel are compared with the experimental and numerical values and Ric-Nays model results which are shown in Fig. 4, the present model results agree satisfactorily with the experimental and numerical data by Aureli and Mignosa as a whole but it was not perfect match due to the presence of solid wall normal to the breach opening in a laboratory flume and it induced strong curvature in the water surface with a vertical pressure distribution. 


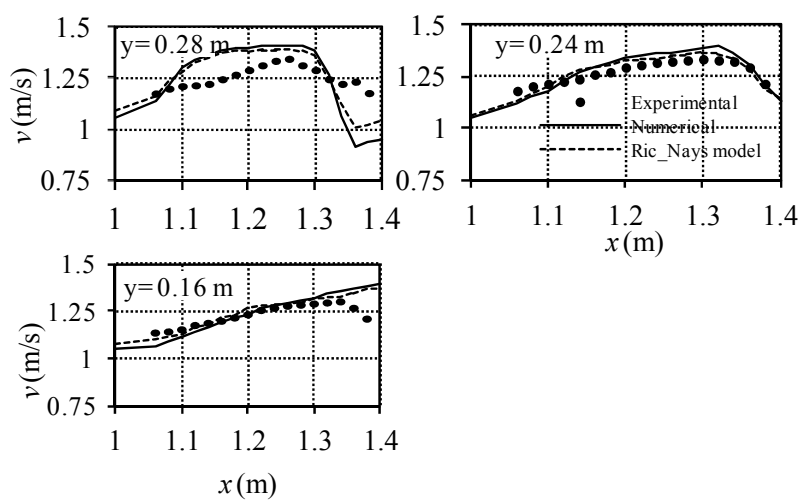

Fig. 4 Longitudinal velocity (v) profiles comparison between RIC-Nays model results with Aureli and Mignosa simulation and experimental data.

\section{EFFECT OF FEATURES OF FLOW AND SEDIMENTATION PATTERNS OVER THE ALLUVIAL FLOODPLAIN}

\subsection{Effect of Inflow Duration}

In Bangladesh, alluvial floodplain was formed by flooding and levees were constructed by dredging from river bed. Normally river bed is lower than the floodplain level. To observe the time dependent evolution process over the floodplain due to levee breach of $100 \mathrm{~m}$ is carried out for inflow discharges of $750 \mathrm{~m}^{3} / \mathrm{s}$ each with duration of 3,10 and 20 minutes, respectively for levee crest height of $2 \mathrm{~m}$ from floodplain and floodplain slope is not taken into consideration are shown in Fig. 5. Initially river water depth observed high and it decreased by increasing inflow duration in the main channel because of river flow diverted to the floodplain through breach with time. Floodplain inundation depth increased in certain duration. It can be concluded that after certain period of time at any specific discharges, inundation depth is not increase in the floodplain with time. The sediment deposition thickness is highest at just downstream of the levee breach and it decreased gradually towards the downstream of the floodplain with increases distance from the breach location. Fig. 6 depicts the transverse distribution of velocity and sedimentation profile in the main channel, levee and floodplain at $x=450 \mathrm{~m}$ on breach with time. Overtopping water passes from the river to the floodplain through the breach initially at high velocity and the velocity reduces with time because of elevation difference in levee crest and floodplain. River water flows from left to right side in the main channel and some portion of water diverted to the floodplain through breach levee. So, it is clearly seen that high velocity is observed at short duration near the breach inside the river, top of the levee and as well as floodplain adjacent to the breach. It is concluded that along the flow direction velocity is high and it decreased with time. Also, velocity distribution pattern is not same in the floodplain due to vortex form in the floodplain. Sediment deposition is occurred near the breach and it decrease along the flow direction in the floodplain. Depth of sedimentation increased with time and it is clearly observed at $x=450 \mathrm{~m}$.
Fig. 7 shows the comparison of flow and sedimentation pattern over floodplain where floodplains slope is taken into consideration as $10 \mathrm{~cm} / \mathrm{km}$. This slope criterion is taken from actual field condition. Due to sloping floodplain, mass transfer rate observed high from river to the floodplain through breach levee. Velocity of flow is changed rapidly in compare to without slope condition and slightly more sediment deposited in the sloping floodplain near to the breach.
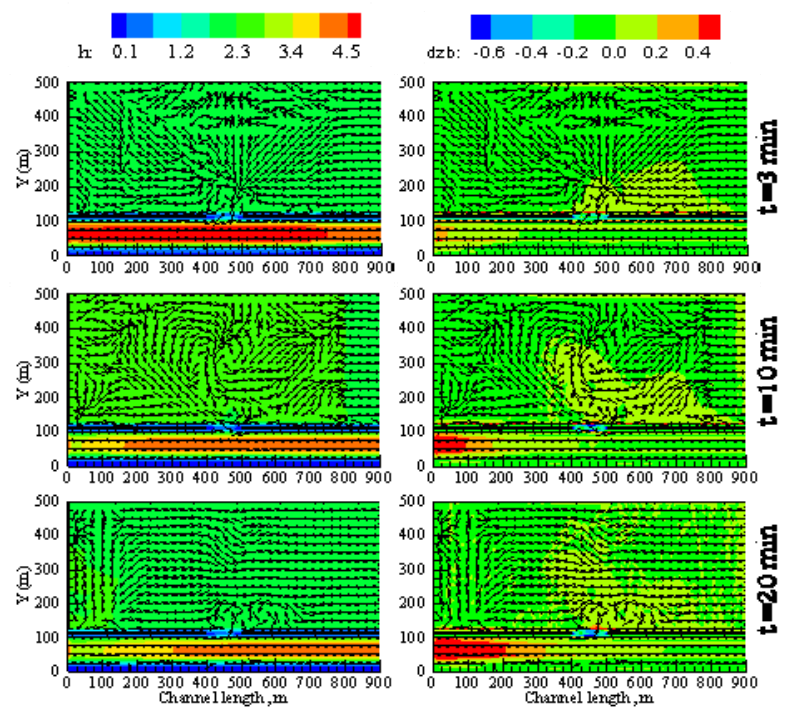

Fig. 5 Simulated flow field in the vicinity of the river, breach levee and floodplain $(S=0)$ where $h_{c}=2 \mathrm{~m}$ from floodplain; contours indicate the water depth $(h)$ and deviation of bed elevation $(d z b)$ with time.
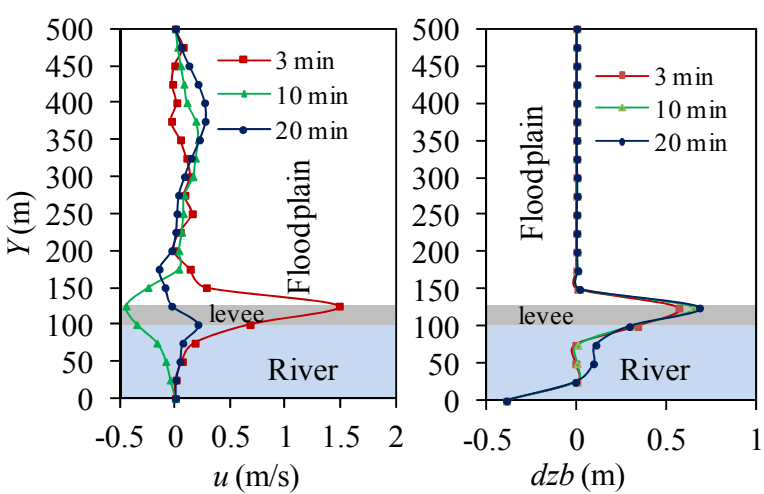

Fig. 6 Transverse distribution of velocity $(u)$ and sedimentation $(d z b)$ profile at $x=450 \mathrm{~m}$ on breach with time where $h_{c}=2 \mathrm{~m}$ from floodplain.

Considering small crest opening as $1 \mathrm{~m}$ from top of levee and sloping floodplain as $S=10 \mathrm{~cm} / \mathrm{km}$, the transverse velocity and sedimentation profile in the main channel, levee and sloping floodplain at $x=450 \mathrm{~m}$ on breach with time are shown in Fig. 8. Inside the river, top of the levee and floodplain adjacent to the breach velocity is observed high and it decreased with time in the main channel. Also, near breach deposition is observed high as larger crest opening.

Using advection time ratio of 100 , the time duration in the simulation corresponds to 33 hours in the field, which is 
within a possible range and the simulation covers long enough time span.
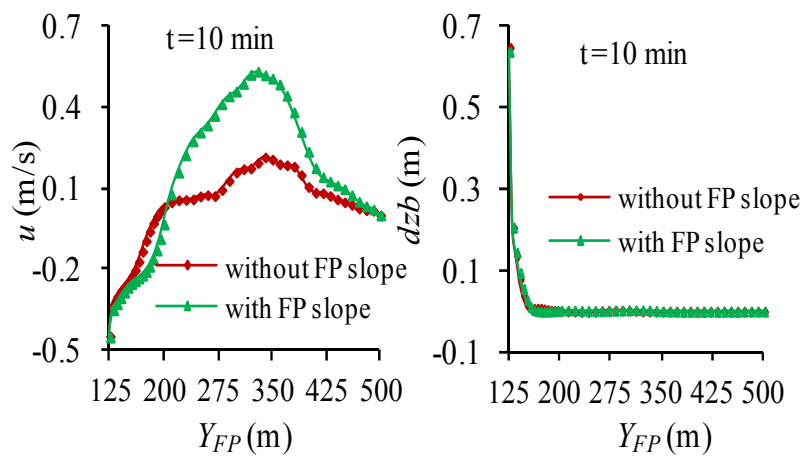

Fig. 7 Comparison of transverse distribution of velocity $(u)$ and sedimentation $(d z b)$ profile in the floodplain $\left(Y_{F P}\right)$ at $x=450 \mathrm{~m}$ on breach considering with and without floodplain slope where $h_{c}=2 \mathrm{~m}$ from floodplain.
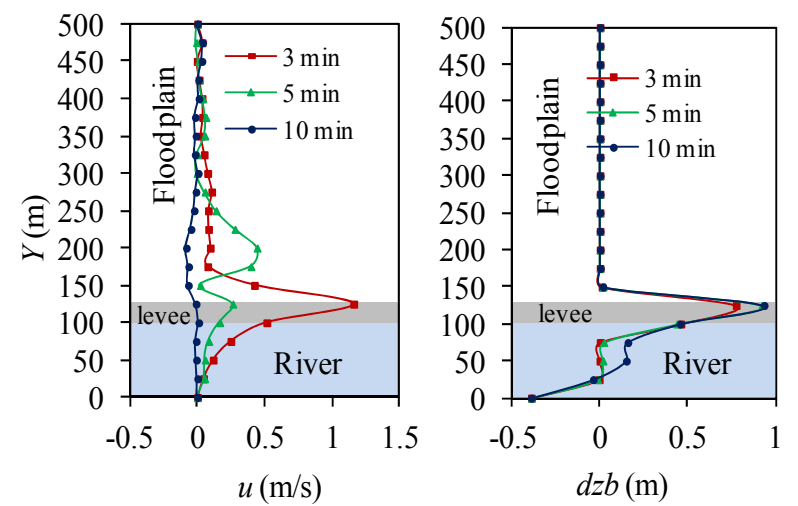

Fig. 8 Transverse distribution of velocity $(u)$ and sedimentation $(d z b)$ profile at $x=450 \mathrm{~m}$ on breach with time where $h_{r}=4 \mathrm{~m}$ from floodplain.

\subsection{Effect of Inflow Discharges}

Inundation and sedimentation patterns over the floodplain at different discharges are shown in Fig. 9. To observe the discharge dependent inundation and sedimentation process over the floodplain due to levee breach of $100 \mathrm{~m}$ is carried out for 15 minutes each with inflow discharges of 700, 750 and $800 \mathrm{~m}^{3} / \mathrm{s}$, respectively. Floodplain inundation depth increased with increase of inflow discharges in the main channel. More area of floodplain sedimentation observed at high inflow discharge in the main channel. Transverse velocity and sedimentation profile in the main channel, levee and floodplain at $x=450 \mathrm{~m}$ on breach with discharge are shown in Fig. 10. Adjacent to the breach inside the river, top of levee and floodplain; velocity observed high at any inflow discharges and then it decreased suddenly in the floodplain due to river water passes through the levee crest at a high gradient to a low gradient in the floodplain. Sediment deposition area is increased and depth decreased by increasing inflow discharges in the main channel.
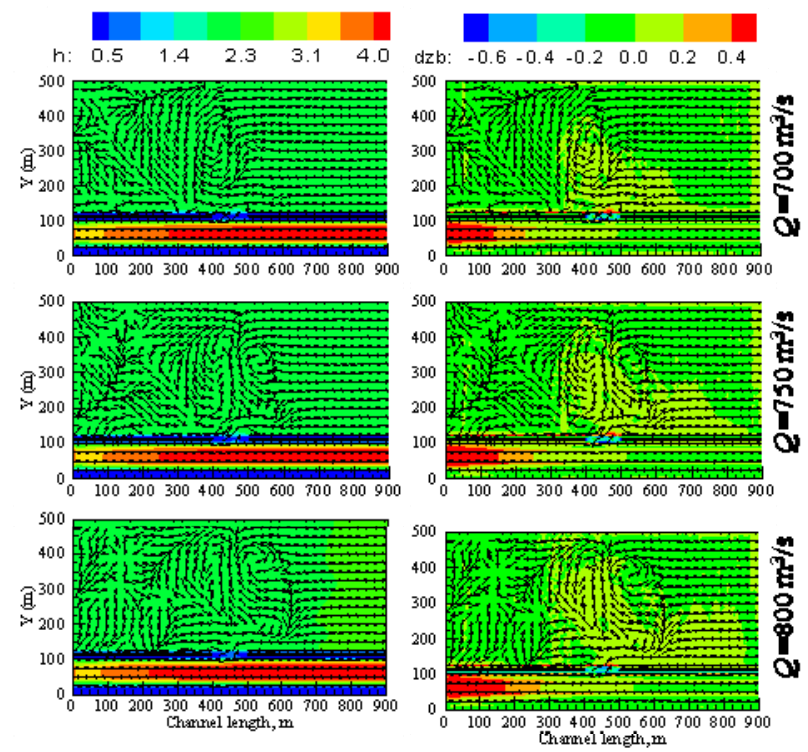

Fig. 9 Simulated flow field in the vicinity of the river, breach levee and floodplain where $h_{c}=2 \mathrm{~m}$ from floodplain; contours indicate the water depth $(h)$ and deviation of bed elevation $(d z b)$ with inflow discharges.
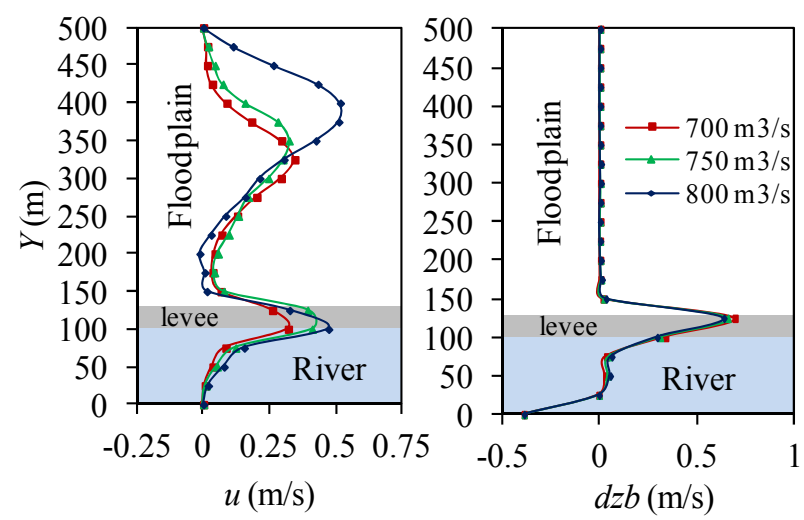

Fig. 10 Transverse distribution of velocity $(u)$ and sedimentation $(d z b)$ profile at $x=450 \mathrm{~m}$ on breach with inflow discharges where $h_{c}=2 \mathrm{~m}$ from floodplain.

\subsection{Effect of Breach Lengths on the Levee}

Levee breach is considered to initiate in the middle of the levee with crest opening. To investigate inundation and sedimentation process over the floodplain with different lengths of levee breaches as $100 \mathrm{~m}, 200 \mathrm{~m}$ and $300 \mathrm{~m}$, respectively are carried out with duration of 15 minutes and discharge of $750 \mathrm{~m}^{3} / \mathrm{s}$ which are shown in Fig. 11 . Floodplain inundation depth increased with large breach opening than smaller one. Sedimentation depth and deposition area is more when overflow water passes at larger breach opening. At different breach opening length, the transverse velocity and sedimentation profile in the main channel, levee and floodplain at $x=450 \mathrm{~m}$ on breach is shown in Fig. 12. Near breach velocity is observed high at small breach opening and the velocity is reduced by increasing breach length in the levee. Sediment depositions took place over the floodplain along the flow direction. 


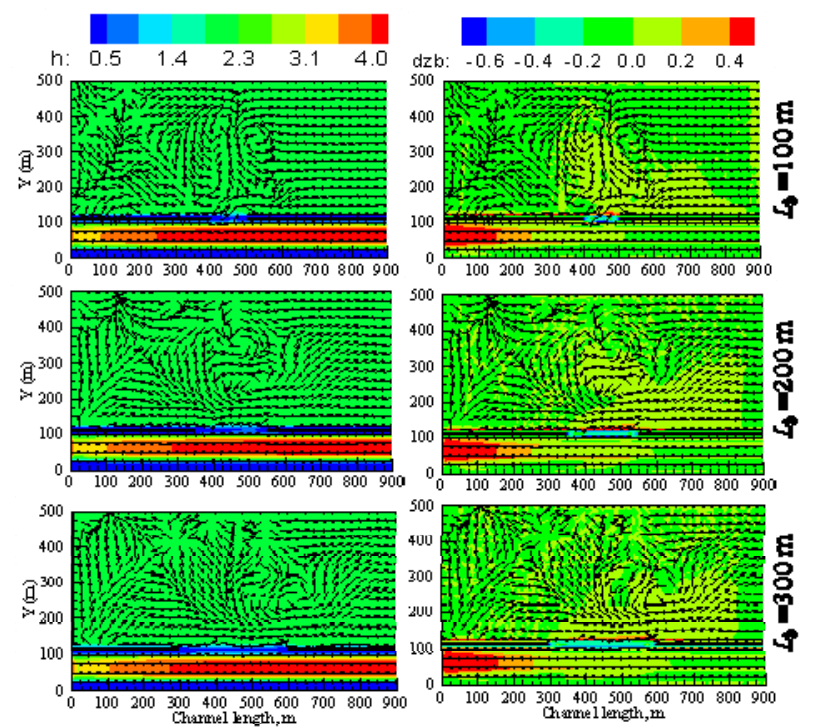

Fig. 11 Simulated flow field in the vicinity of the river, breach levee and floodplain where $h_{c}=2 \mathrm{~m}$ from floodplain; contours indicate the water depth $(h)$ and deviation of bed elevation $(d z b)$ with breaching lengths.
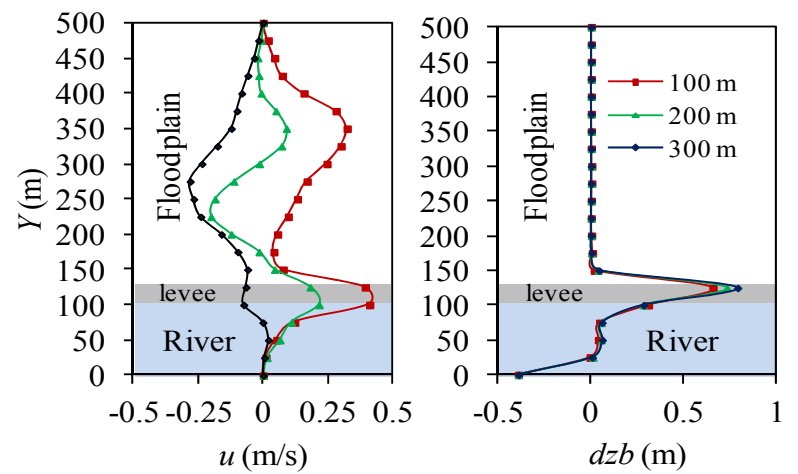

Fig. 12 Transverse distribution of velocity $(u)$ and sedimentation $(d z b)$ profile at $x=450 \mathrm{~m}$ on breach by changing breach length where $h_{c}=2 \mathrm{~m}$ from floodplain.

\section{LEVEE DEFORMATION DUE TO OVERFLOW THROUGH BREACH}

Levee deformation is observed along the river flow direction at top of the levee $(y=115 \mathrm{~m})$. To investigate levee deformation through overflow breach of $100 \mathrm{~m}$ is carried out for 1 and 20 minutes, respectively and discharges, $750 \mathrm{~m}^{3} / \mathrm{s}$ and $1550 \mathrm{~m}^{3} / \mathrm{s}$ for levee crest height of $2 \mathrm{~m}$ and $4 \mathrm{~m}$ from floodplain, respectively are shown in Fig. 13. We have seen that vertical deformation observed $0.4 \mathrm{~m}$ in 1 minute at $h_{c}=4 \mathrm{~m}$ and no vertical erosion at $h_{c}=2$ $\mathrm{m}$ whereas $0.65 \mathrm{~m}$ and $0.45 \mathrm{~m}$ vertical erosion observed in 20 minutes at $h_{c}=4 \mathrm{~m}$ and $h_{c}=2 \mathrm{~m}$, respectively.

Not only vertical erosion but also more horizontal erosion is observed when overtopping water passes through small crest opening in breach levee at $h_{c}=4 \mathrm{~m}$. It can be concluded that levee breach overflow causes more deformation and consequences as more sedimentation in the floodplain at small crest opening than larger one. Obviously, breaching section of higher duration is higher, and it results that the large amount of discharge causes serious inundation as well as sedimentation in the floodplain. To observe levee deformation is carried out for 15 minutes through breaches of $100 \mathrm{~m}$ and different
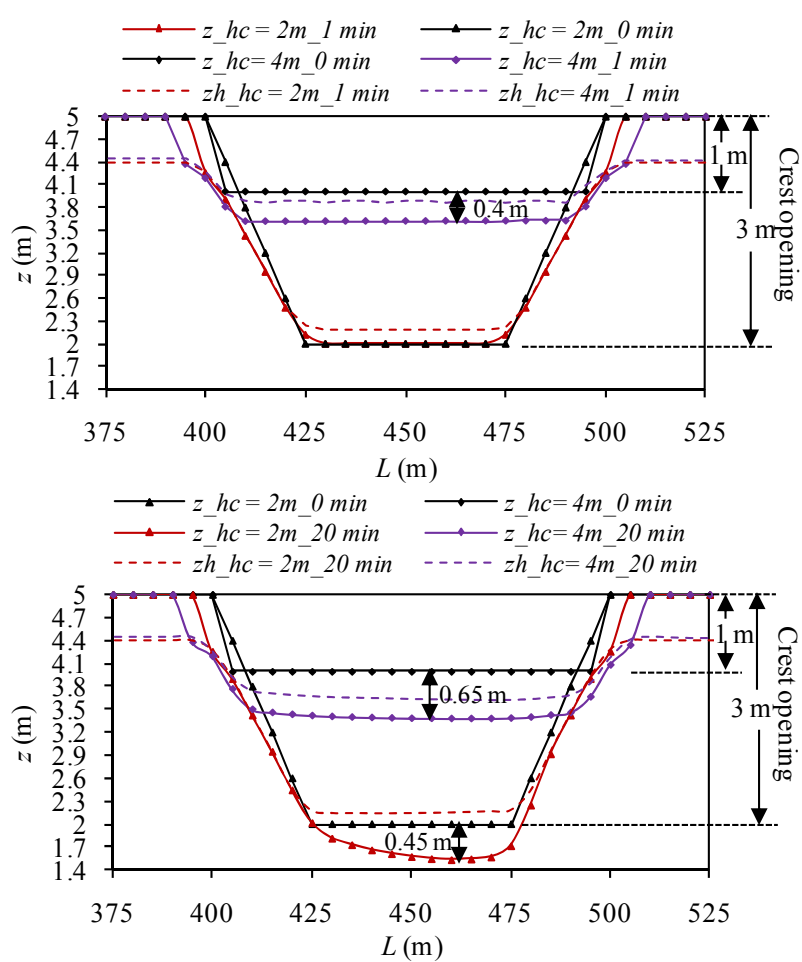

Fig. 13 Time dependent comparison of levee evolution process with crest opening at top of the levee $(y=115 \mathrm{~m})$.
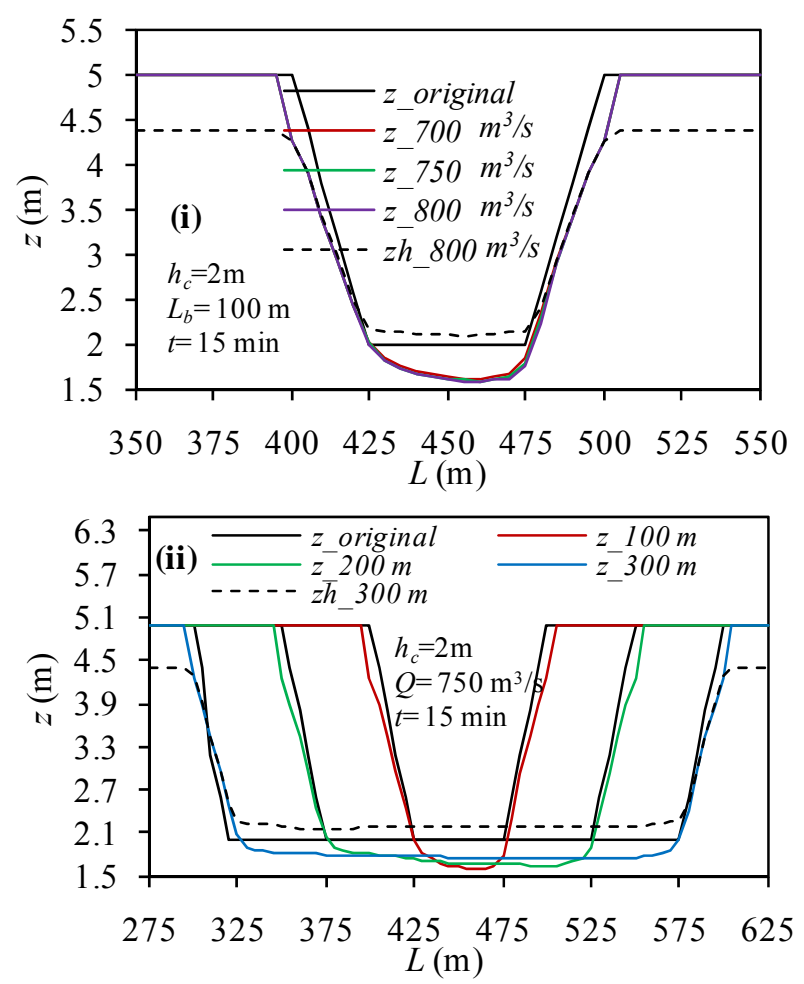

Fig. 14 Levee deformation at top of the levee $(y=115 \mathrm{~m})$ with (i) inflow discharges; and (ii) different breach lengths.

discharges of 700,750 and $800 \mathrm{~m}^{3} / \mathrm{s}$, respectively [Fig. 14 (i)] also different initial breach opening as 100, 200 and 
$300 \mathrm{~m}$ and discharge of $750 \mathrm{~m}^{3} / \mathrm{s}$ [Fig. 14 (ii)]. In discharge dependent conditions (i), slightly more vertical erosion is observed with inflow discharge increases in the main channel and breach length dependent conditions (ii), breach enlarged in vertical and horizontal direction for all length of breaches but vertical enlargement is observed more when water passing through small breach $(100 \mathrm{~m})$ opening as compared to larger $(300 \mathrm{~m})$ one.

\section{CONCLUSIONS}

The conclusions drawn are as follows:

i. Floodplain inundation depth is increased in certain duration. Inundation depth increased with increase of inflow discharge in the main channel and with large breach opening than smaller one.

ii. Near breach velocity is observed high both in the river and in the floodplain at short duration and any inflow discharges in the main channel. Velocity is reduced by increasing breach length in the levee.

iii. Sediment deposition is occurred near the breach and it decrease along the flow direction in the floodplain. Deposition depth increased with time, discharges in the main channel and breach length in the levee.

iv. Levee breach overflow causes more deformation and consequences as more sedimentation in the floodplain at small crest opening than larger one.

However, details laboratory experiments and field observation are required to get more clarification about the process of levee breach inundation and sedimentation as well as inhabitant's suffering who are lived in the alluvial floodplain. In the study area there are different land use pattern and effect of flood disasters are not same in everywhere. In order to get basic differences of flood disasters using various land type of study area we have plan for future study.

\section{REFERENCES}

[1] Ahmed SMU, Hogue MM and Hossain S, "Floods in Bangladesh: A Hydrological Analysis," Final Report R01/92, Institute of Flood Control and Drainage Research (IFCDR), Bangladesh University of Engineering and Technology(BUET), Dhaka, 1992, pp.1-5.

[2] Ashida K and Michiue M, "Studies on bed load transportation for non-uniform sediment and river bed variation," Disaster Prevention Research Institute Annuals, Kyoto University, No 14B, 1972, pp. 259-273 (in Japanese).

[3] Aureli $\mathrm{F}$ and Mignosa $\mathrm{P}$, "Comparison between experimental and numerical results of 2D flows due to levee-breaking," XXIX IAHR Congress Proceedings, Theme C, September 16-21, 2001, Beijing, China
[4] Engelund F, "Flow and Bed Topography in Channel Bend" J. of Hydraulic Division, ASCE, Vol.100, No. 11, 1974, pp. 1631-1648.

[5] Fujita $Y$ and Tamura T, "Enlargement of breaches in flood levee on alluvial plains," J. of Natural Disaster Science, Vol. 9, No. 1, 1987, pp. 37-60.

[6] Hasegawa K, "Hydraulic research on planimetric forms, bed topographies and flow in alluvial river," $\mathrm{PhD}$ Dissertation, Hokkaido University, Japan (in Japanese).

[7] Hossain MZ and Sakai T, "Severity of Flood Embankments in Bangladesh and Its Remedial Approach," Agricultural Engineering International: the CIGR E-journal, Manuscript LW 08 004, Vol. X, May 2008.

[8] Islam MZ, Okubo K and Muramoto Y, "Embankment Failure and Sedimentation over the Flood Plain in Bangladesh: Field Investigation and Basic Model Experiments," J. of Natural Disaster Science, Vol.16, No.1, 1994, pp. 27-53.

[9] Islam MZ, Okubo K, Muramoto $\mathrm{Y}$, and Morikawa H, "Experimental Study on Sedimentation over the Floodplain due to River Embankment Failure," Bulletin of the Disaster Prevention Research Institute, Kyoto University, 44(2), 1994, pp. 69-92.

[10] Report on Flood Hazard Model, "Index Based Flood Insurance Products for Sirajganj District, Bangladesh,: Institute of Water Modeling (IWM), Dhaka, Bangladesh, 2010, pp 1-48.

[11] Sarker MH, Huque I, Alam M and Koudstaal R, "Rivers, chars, char dwellers of Bangladesh," Int. J. of River Basin Management, Vol. 1, 2003, pp. 61-80.

[12] Shimizu Y and Itakura T, "Calculation of flow and bed deformation with a general non-orthogonal coordinate system," Proc. of XXIV IAHR Cong. Madrid, Spain, Vol. C, 1991, pp. 241-248.

[13] Tingsanchali T and Karim MF, "Flood hazard and risk analysis in the southwest region of Bangladesh," J. of Hydrological Process, Vol.19, 2005, pp. 2055-2069.

[14] Tsujimoto T, Mizoguchi A and Maeda A, "Levee breach process of a river by overflow erosion," Int. Conf. of Fluvial Hydraulics, Portugal 6-8 Sep. 2006.

[15] Yabe T and Ishikawa T, "A numerical cube interpolated pseudoparticle (CIP) method without time splitting technique for hyperbolic equations" J. of Physical society of Japan, Vol. 59, No. 7, 1990, pp. 2301-2304.

\footnotetext{
International Journal of GEOMATE , Oct. 2011, Vol. 1, No.1 (Sl. No. 1)

MS No. 11 received September 1, 2011, and reviewed under GEOMATE publication policies.

Copyright (C) 2011, International Journal of GEOMATE. All rights reserved, including the making of copies unless permission is obtained from the copyright proprietors. Pertinent discussion including authors' closure, if any, will be published in the Oct. 2012 if the discussion is received by April 2012.

Corresponding Author: Md. Serazul Islam
} 